\title{
Investments and Finance when Liquidation is costly
}

Citation for published version (APA):

Letterie, W. A., \& Bruinshoofd, A. (2004). Investments and Finance when Liquidation is costly. De Economist, 152(1), 21-45. https://doi.org/10.1023/B:ECOT.0000019526.85502.09

Document status and date:

Published: 01/01/2004

DOI:

10.1023/B:ECOT.0000019526.85502.09

Document Version:

Publisher's PDF, also known as Version of record

\section{Please check the document version of this publication:}

- A submitted manuscript is the version of the article upon submission and before peer-review. There can be important differences between the submitted version and the official published version of record.

People interested in the research are advised to contact the author for the final version of the publication, or visit the DOI to the publisher's website.

- The final author version and the galley proof are versions of the publication after peer review.

- The final published version features the final layout of the paper including the volume, issue and page numbers.

Link to publication

\footnotetext{
General rights rights.

- You may freely distribute the URL identifying the publication in the public portal. please follow below link for the End User Agreement:

www.umlib.nl/taverne-license

Take down policy

If you believe that this document breaches copyright please contact us at:

repository@maastrichtuniversity.nl

providing details and we will investigate your claim.
}

Copyright and moral rights for the publications made accessible in the public portal are retained by the authors and/or other copyright owners and it is a condition of accessing publications that users recognise and abide by the legal requirements associated with these

- Users may download and print one copy of any publication from the public portal for the purpose of private study or research.

- You may not further distribute the material or use it for any profit-making activity or commercial gain

If the publication is distributed under the terms of Article $25 \mathrm{fa}$ of the Dutch Copyright Act, indicated by the "Taverne" license above, 
INVESTMENT AND FINANCE WHEN LIQUIDATION IS COSTLY***

BY

ALLARD BRUINSHOOFD* AND WILKO LETTERIE**

Summary

In this paper we investigate to what extent expected liquidation costs affect the dependence of a firm's investment decision on available finance. We hypothesise that comovement of firm and industry sales measures such costs, which create a premium on external finance and make investment more sensitive to the availability of internal funds. Supportive evidence for this conjecture is obtained from the investment behaviour of a sample of 206 large Dutch manufacturing firms observed during the period 1983-1996. We also demonstrate that our measure of expected liquidation costs has additional explanatory power over other proxies for the premium on external finance - like leverage, retention practice and firm size.

Key words: investment, finance, liquidation cost

\section{INTRODUCTION}

The relevance of the observed connection between investment and finance rises on the policy agenda when the economic tide turns. An environment of downward revisions of earnings forecasts and accompanied cuts in budgets for corporate investment serves to re-accentuate how financing constraints at the firm-level can propagate downturns in the aggregate output growth of an economy. Economic downturns furthermore revive the perception of liquidation as possible realworld events when even large firms see reserves evaporating rapidly.

* Corresponding author: De Nederlandsche Bank, Research Department, P.O. Box 98, 1000 AB Amsterdam, The Netherlands.

** Department of Management Sciences, Maastricht University.

*** We thank Bertrand Candelon, Martin Carree, Martin Fase (the editor), Clemens Kool, Gerard Pfann, Fabio Schiantarelli, Elmer Sterken, Bas ter Weel, participants in internal seminars at Maastricht University, BIRC's seminar on Investment Decisions by Firms, Statistics Netherlands' seminar on Dutch Micro-Data Research and the SMYE2000 in Copenhagen and two anonymous referees for their useful comments. Letterie acknowledges support by the Dutch Foundation for Scientific Research PIONIER program. The research is furthermore supported by a grant from the Maastricht research school on Economics of TEchnology and ORganisations (METEOR) and was partially carried out at the Centre for Research of Economic Micro-data (CeREM) of Statistics Netherlands. The views expressed are those of the individual authors and do not necessarily reflect official positions of Statistics Netherlands or De Nederlandsche Bank.

De Economist 152, 21-45, 2004.

(C) 2004 Kluwer Academic Publishers. Printed in the Netherlands. 
In this paper we examine to what extent costly liquidation has an impact on the dependence of corporate investment on available finance. The underlying idea is as follows. The firm's ability to finance planned investment improves if the firm can provide collateral to a creditor when it takes out a loan. A firm is more able to provide collateral if - all else equal - its expected liquidation costs are low, i.e. its assets are expected to fetch a good price in a fire sale. Hence, a firm's ability to raise (collateralized) debt improves when expected liquidation costs are low. In contrast, when liquidation costs are expected to be high, we expect that a firm will find it difficult to raise additional collateralized debt. A firm may then reconsider its investment plans or resort to uncollateralized loans, which are typically more expensive (cf. Hubbard (1998)). ${ }^{1}$

The connection between expected liquidation costs and the capital structure is illustrated by Shleifer and Vishny (1992), who consider theoretically expected liquidation costs for firms that operate in sectors characterised by mainly idiosyncratic or industry-wide performance shocks. They argue that specifically in the latter case fire sales attract few industry insiders, because that is the scenario where all industry insiders face poor performance at the same time. In conjunction with sector specificity of assets this implies that liquidation costs are higher for firms that operate in sectors with mainly industry-wide performance shocks. Such firms have lower debt capacity as a result. Worthington (1995) explores the role of sector specificity of assets in the connection between investment and finance empirically. She finds that firms operating in sectors for which assets are highly specific or 'sunk' have more difficulty in raising external finance for investment. The contribution of the present paper is that we examine the role of firm-specific liquidation cost perceptions on the dependence of investment on finance. Specifically, assuming sector specificity of assets, we consider whether firms experience idiosyncratic or industry-wide performance shocks by taking the cyclical performance of a firm relative to its direct environment as a measure of the probability that assets may be sold to industry peers in a fire sale.

We estimate reduced-form investment equations on a balanced panel of 206 large Dutch firms. In addition to expected firm-specific liquidation costs, for benchmarking purposes we also assess the impact of a few alternative firm-level proxies for financing constraints on the sensitivity of investment to financial variables. Our main empirical findings are the following. First, firms for which we expect liquidation costs to be lowest are also the firms for which investment is least dependent on increases in net worth, suggesting that costly liquidation is linked with financing constraints in investment. Second, we find that firms with low expected liquidation costs do not retain a typically large or small fraction of earnings, nor are they particularly larger or smaller than their peers with high expected liquidation costs. Their degree of leverage does not differ either. This

1 Borrowing without providing collateral may also lead to credit rationing (cf. Stiglitz and Weiss (1981)). 
leads us to conclude that costly liquidation has additional explanatory power over other proxies for financing constraints - like retention practice, firm size, and leverage - that have frequently been used in the literature. ${ }^{2}$

The paper proceeds as follows. Section 2 discusses the empirical analysis of investment subject to financing constraints. In section 3 we discuss the theoretical connections between liquidation, finance, and investment. Here we also introduce the data and describe our empirical measure of liquidation costs. Estimation results are presented and discussed in section 4 . There, we also examine to what extent our classification of firms on the basis of liquidation costs reflects the information embedded in some well-known classification schemes. Section 5 summarises and concludes.

\section{THE EMPIRICAL INVESTMENT EQUATION}

We characterise optimal firm-level investment with a simple sales accelerator type investment model:

$$
\frac{I_{t}}{K_{t-1}}=\alpha_{0}+\alpha_{1} \frac{I_{t-1}}{K_{t-2}}+\alpha_{2} \ln \frac{S_{t}}{S_{t-1}}+\alpha_{3} \ln \frac{S_{t}}{K_{t-1}}+\varepsilon_{t},
$$

where $I$ captures investment in fixed assets, $S$ stands for sales, $K$ for capital stock, and $\varepsilon$ is an error term. ${ }^{3}$ Equation (1) is an empirical characterization of a capital stock optimisation problem that does not consider the financing decision. This is justified under the assumption of perfect capital markets so that the irrelevance theorem holds. However, financing becomes non-trivial in the investment decision when firms face binding financing constraints. In the latter case, a proper characterisation of investment should take into account the financing side as well. In particular the investment decision now also depends on changes in internally available funds (cf. Fazzari et al. (1988)). We add cash flow $(C f)$ to the investment equation to capture this financing channel. We expect cash flow to affect investment positively - after controlling for investment opportunities - when financing constraints are relevant and more strongly so when we expect firms to

2 For studies using retention practice, see for instance Fazzari et al. (1988), Oliner and Rudebusch (1990), Bond and Meghir (1994), Gilchrist and Himmelberg (1995), van Ees et al. (1998); for studies using firm size see for instance Devereux and Schiantarelli (1990), Carpenter et al. (1994), Gilchrist and Himmelberg (1995), Hu and Schiantarelli (1998), van Ees et al. (1998); for studies using leverage see for instance Whited (1992), van Ees et al. (1998), Hu and Schiantarelli (1998). Refer to Schiantarelli (1996) or Hubbard (1998) for more elaborate overviews.

3 This investment function results for instance from a simple neo-classical demand-for-capital function, if we impose an $\operatorname{ADL}(2,1)$ specification of the capital stock adjustment process, and disregard (changes in) the real rental price of capital (cf. Bond and van Reenen (1999)). For alternative theoretical models resulting in empirical investment equations very similar to (1), see for instance Galeotti et al. (1994), Harris et al. (1994), or Schiantarelli and Sembenelli (2000). 
face binding constraints with a larger probability, for example because they have higher expected liquidation costs. There is by now a lively debate in the literature concerning the interpretation of the (excess) sensitivity of investment to cash flow. On the one hand, Erickson and Whited (2000) demonstrate that the empirical finding that investment of financially constrained firms is excessively sensitive to cash flow may be due to a measurement error in investment opportunities. On the other hand, Gilchrist and Himmelberg (1998) take into account that cash flow may contain information about unobserved innovations in investment opportunities and still find patterns of investment cash flow sensitivity that are supportive of a financing constraints explanation. Our approach to limit the possibility that cash flow accounts for unobserved investment opportunities captured by the error term is to treat it as a potentially endogenous variable and instrument it with lags of its own value.

Additionally, we implement the idea developed by Fazzari and Petersen (1993) that the impact of working capital investment $(\Delta W c)$ in the (fixed capital) investment equation also signals the relevance of financing constraints. Here we apply the idea that investment in working capital is important to the firm in addition to investment in fixed capital. Now suppose that, despite our use of an instrumental variables approach, a positive cash flow sensitivity of investment is still artificial and reflects nothing more than the correlation of (predicted) cash flow with unobserved innovations in investment opportunities. ${ }^{4}$ In this scenario, an unobserved improvement in investment opportunities would provide an incentive for the firm to increase investment in both fixed and working capital. Hence, unobserved innovations to investment opportunities would produce not only a spurious (positive) correlation between cash flow and fixed capital formation, but likewise between investment in fixed and working capital. Suppose, alternatively, that a positive cash flow sensitivity correctly measures the impact of financing constraints. Then, working capital competes with investment in fixed assets for a limited pool of internal funds. Hence, investment in fixed capital - given the amount of internal finance available - can be expanded only at the expense of lower investment in working capital. A negative parameter estimate on working capital investment is the result.

Investment in working capital is therefore added to the investment equation to provide additional insight into the relevance of financing constraints. A negative parameter estimate for working capital investment signals the competition of fixed and working capital investment for limited internal resources and therefore supports the interpretation of a positive cash flow sensitivity of investment as stem-

\footnotetext{
4 For instance, cash flow may be a leading indicator of future investment opportunities. Then cash flow predictions based on past cash flow realisations may still correlate with (unobserved) innovations in investment opportunities.
} 
ming from financing constraints. ${ }^{5}$ Similar to the case of cash flow, we expect working capital investment to compete particularly strongly with fixed assets for funding when the firm has a larger probability of facing binding financing constraints. As in the case of cash flow, however, we have to consider the possibility that working capital investment may be endogenous in the fixed capital investment equation. Specifically, the argument can be made that firms facing a positive shock to investment opportunities may reduce working capital investment not because of binding financing constraints, but simply because this is the least costly short-run adjustment. ${ }^{6}$ Hence we also instrument working capital investment (with lags of its own value).

The empirical investment equation is then:

$$
\begin{aligned}
\frac{I_{i t}}{K_{i(t-1)}}= & \beta_{0} \frac{I_{i(t-1)}}{K_{i(t-2)}}+\beta_{1} \ln \frac{S_{i t}}{S_{i(t-1)}}+\beta_{2} \ln \frac{S_{i t}}{K_{i(t-1)}}+\beta_{3} \frac{C f_{i t}}{K_{i(t-1)}} \\
& +\beta_{4} \frac{\Delta W c_{i t}}{K_{i(t-1)}}+\varepsilon_{i t},
\end{aligned}
$$

where the variables are indexed by firm (i) and year $(t), \varepsilon=\lambda_{i}+\eta_{t}+\nu_{i t}$ is the error term that contains both time $\left(\lambda_{t}\right)$ and firm $\left(\eta_{i}\right)$ specific effects and a residual white noise term $\left(\nu_{i t}\right) .^{7}$

For unbiased estimates on sales growth and the sales-to-assets ratio, we also instrument these variables appropriately in the empirical analysis. Lastly, since lagged investment enters on the right hand side of the regression equation and we model a firm specific error component, we have to consider and correct for the correlation between lagged investment and the regression error. We use the Arellano and Bond (1991) dynamic panel estimation methodology to compute consistent parameter estimates and refer to Appendix A for the details.

\section{LIQUIDATION, FINANCE, AND INVESTMENT}

In this section we elaborate on the theoretical arguments that relate costly liquidation to the interdependence of corporate investment and finance. Specifically, in subsection 3.1 we first examine the role of costly liquidation on the cost of external finance and subsequently we discuss how liquidation costs - via costly reversibility - affect corporate investment demand. We then turn to the empirical

5 Furthermore, Fazzari and Petersen (1993) suggest that if working capital is excluded from the empirical model, cash flow sensitivities may be underestimated.

6 See Shyam-Sunder and Myers (1999) for a similar argument in the case of capital structure adjustment.

7 For the remainder of the analysis the book value of assets proxies for a firm's capital stock, which is an admissable, though imperfect proxy (e.g. Weigand and Audretsch (1999)). 
measurement of liquidation costs. In subsection 3.2 we introduce the data and in subsection 3.3 we present and explain our proxy for liquidation costs.

\subsection{Theoretical Considerations}

Reversibility of investment affects both the demand for external funds and its supply. We discuss these two issues in turn. On the one hand, costly liquidation affects the interdependence of corporate investment and finance via the supply of costly external finance. Shleifer and Vishny (1992) illustrate the argument theoretically by considering expected liquidation costs for firms that operate in sectors characterised by mainly idiosyncratic or industry-wide performance shocks. In case of idiosyncratic shocks, firms forced to liquidate likely find well-performing industry peers - considered to be the next-best users of a firm's assets - who are interested in purchasing its assets. These industry peers are willing to pay a price close to the true value of the assets. In contrast, if performance shocks are mainly industry-wide, industry peers find no interest in purchasing the assets of a liquidating firm. Then, assets must be sold to industry outsiders at values below their true value. The discount arises from the lower value that industry outsiders derive from a firm's specific assets, but also from their fear to overpay as they cannot value them properly (effectively considering these assets as lemons). This makes liquidation costly and assets less valuable as collateral to loans. The result is rising marginal costs of debt and possibly a lower debt capacity or a binding debt capacity constraint (cf. Hubbard (1998)). For a given demand for investment, therefore, we expect firms to be more financially constrained when liquidation costs are higher.

On the other hand, costly liquidation associates with costly reversibility, or partial irreversibility, because of the wedge it drives between purchase and selling price of a firm's capital stock (eg. Abel and Eberly (1994)). Let us briefly consider how costly reversibility affects a firm's optimal investment demand. Dixit and Pindyck (1994) consider costly reversibility of investment when the firm has the option to invest now or wait until uncertainty over the profitability of investment is resolved. Uncertainty in combination with costly reversibility may delay investment when there is an option to start the same project at a later date. This lowers current investment demand and - in a financing constraints setting with a given level of internal funds - reduces the probability that a firm is in need of costly external finance.

Theoretically, therefore, the impact of costly liquidation on the probability that firms experience financing constraints is ambiguous. On the one hand, high liquidation costs limit the supply of external funds and/or raise its price. Through this supply channel, liquidation costs increase the probability that firms face financing constraints. Hence the sensitivity of investment to cash flow rises with expected liquidation costs when this channel dominates. On the other hand, costly liquidation makes waiting more valuable and reduces current investment demand. 
This lowers the demand for external funds and results in a lower probability that firms face financing constraints. We thus hypothesise empirically that if this $d e-$ mand channel dominates, then the cash flow sensitivity of investment for firms with the highest expected liquidation costs should be lowest. Which of these two channels dominates must ultimately be assessed empirically.

\subsection{The Data}

In the empirical analysis we make use of Statistics Netherlands' SFGO sample, which collects balance sheet and income statement data on a nonrandom sample of Dutch firms. The sample is devised to collect information on the entire population of Dutch firms for which the total balance sheet length exceeds DFL 20 million in current prices. In practice, the annual response rate is roughly eighty percent, so that the SFGO sample includes nearly 30,000 firm-years of observation, covering the period 1977-1997. We extract from this sample a balanced panel of Dutch manufacturing firms (sectors 20-39 according to SBI74 classification). In this, we follow the majority of papers in this field of research. Due to attrition, we only select the years ranging from 1983 to 1996 so that we have information on all the relevant variables in the investment equation for a total of 206 firms.

Our sample thus consists very clearly of particularly large Dutch firms. Furthermore, the choice for a balanced panel possibly selects from this data the most financially healthy firms and likely also the most mature firms. Large and mature firms are typically regarded to face the smallest premium on external finance. ${ }^{8}$ In terms of the present analysis, therefore, we may be using a sample that is particularly biased against finding any effects of financing constraints in investment. Hence our estimated investment cash flow sensitivities are conservative and the implied relevance of liquidation costs in explaining financing constraints should be considered as a lower bound of its importance in the representative Dutch manufacturing firm.

\subsection{Measuring Liquidation Costs}

We compute an empirical measure of expected liquidation costs that corroborates with Worthington's (1995) empirical application of asset liquidity to the dependence of corporate investment on the availability of finance. Specifically, Worthington (1995) argues that liquidation costs are expected to be higher for firms that operate assets that are highly specific or 'sunk,' which translates empirically into firms operating assets for which an active second-hand or rental market is

8 See for instance Devereux and Schiantarelli (1990), Oliner and Rudebusch (1992), Schaller (1993), Carpenter et al. (1994), Galeotti et al. (1994), Chirinko and Schaller (1995), Gilchrist and Himmelberg (1995) and (1998), Hubbard et al. (1995), and Jaramillo et al. (1996). 
lacking. Worthington assesses the extent of a second-hand or rental market on a sectoral basis. We agree with the emphasis on asset specificity in the explanation of financing constraints, but feel uncomfortable with a sectoral assessment of liquidation costs, as it by-passes interesting within-sector variation in expected liquidation costs.

Instead, we propose a measure of liquidation costs that emphasizes to what extent firms suffer from idiosyncratic or industry-wide performance shocks. With this emphasis, liquidation costs may differ widely between firms in the same sector, as is already illustrated by Shleifer and Vishny's (1992) prediction that 'growth assets such as high technology firms and cyclical assets [...] are illiquid because industry buyers of these assets are likely to be themselves severely credit constrained when the owners of these assets need to sell' (Shleifer and Vishny (1992), p. 1359). While some economic sectors are clearly more technologically advanced than others - suggesting sector-specific liquidation costs - also within sectors there are technological leaders and laggards. We therefore characterize liquidation costs at the firm level as proposed by Guiso and Parigi (1999) and 'construct an indicator of asset liquidity at the firm level [by] measuring the correlation [of output] of the firm with its industry' (Guiso and Parigi (1999), p. 208). The higher this correlation, the more firm performance comoves with industry performance, resulting in lower asset liquidity and higher expected liquidation costs. Comovement - which is how we label this correlation for the remainder of this analysis - relates to liquidation costs by the following argument. High-comovement firms perform exceptionally well when the sector as a whole performs well, but also perform exceptionally poor when the sector as a whole performs poorly. Hence, when the high-comovement firm approaches financial distress, its industry peers - due to asset specificity the next-best users of its assets - also experience poor performance, resulting in high expected liquidation costs for high-comovement firms.

One explanation of why some firms display high and others low comovement may be offered in terms of differing technological or innovative content of the product sold. Along this line of reasoning, high comovement firms offer products of average technological or innovative content in large quantities, which makes them susceptible to demand constraints and implies that their sales follow industry performance. In contrast, low comovement firms - by offering products of either superior or inferior technological or innovative content - operate on separate segments of the sector's sales market and are therefore less susceptible to demand constraints. Unfortunately, our data lack information on product heterogeneity and hence do not allow us to explore this conjecture empirically.

It is important to stress at this point that an empirical measure of expected liquidation costs results from the cyclical performance of a firm relative to its industry peers. As such, we do not intend to sort out as high-comovement firms those firms that perform well on average. Rather, we intend to sort out the firms that perform well when the sector as a whole performs well, but perform poorly 
when the performance of the sector deteriorates. Put differently, firms that perform well regardless of what happens to sector performance are unlikely to score points in terms of comovement. ${ }^{9}$

The innovative feature of our measure of expected liquidation costs is that it is specific to a firm and builds on the relation between a firm and its environment. Specifically, we measure comovement as the correlation between firm and industry real sales growth rates. ${ }^{10}$ To that end, we sort the 206 firms in our sample into nineteen 2-digit manufacturing sectors and obtain sector real sales growth rates from Statistics Netherlands (see Appendix B for computational details). We use the period 1983-1991 to compute comovement. ${ }^{11}$ The resulting comovement variable varies from -0.90 to 0.92 among firms, but for each firm separately it is a constant. Mean and median comovement is 0.07 and 0.11 , respectively. We admit that the 9-year correlation between firm and sector sales as a proxy for the cyclical performance of a firm relative to its peers likely contains some noise. For that reason, we do not want to consider uninformatively small differences in comovement as differences in the expected liquidation costs of a firm (cf. Fazzari et al. (2000)). Instead, for the remainder of the analysis we define three relatively broad classes of comovement. We consider firms with comovement measures among the bottom 25 percent of the comovement distribution to display low comovement (for these firms comovement is below -0.21). Similarly, the top 25 percent of this distribution is considered to display high comovement (for these firms comovement is in excess of 0.36). The remaining firms constitute our reference group; they display medium comovement.

Table 1 indicates which types of firms are considered to be financially constrained on the basis of comovement. Investment is roughly equal for low and medium comovement firms, but considerably lower for high comovement firms. This observation is supportive of a financing constraints explanation; costly external finance curtails a firm's investment. We also observe from the table that high-comovement firms display a slower sales growth and a lower rate of long term debt accumulation. Especially this last observation fits the hypothesis that comovement associates with financing constraints through a lower expected liquidation value of a firm's assets: more costly liquidation makes assets less valuable as collateral to loans and thus hampers debt accumulation. At the same time,

9 In the next section we will demonstrate empirically that our classification of firms as least or most likely to face financing constraints on the basis of comovement does not mimic the results of a classification based on average firm-level sales growth.

10 Alternatively, we have measured comovement as the correlation between firm and industry real sales levels. This does not change any of the conclusions that we draw later on, however.

11 We can only use the 1983-1992 or the 1993-1996 period to compute this correlation due to a revision of the standard industry classification from 1992 to 1993 . We use the longer period to minimise the impact of outliers and get a better estimate of structural comovement. We omit 1992 to ensure that the estimation period is long enough as discussed later in section 4.2. Furthermore, due to data limitations we cannot compute comovement for fourteen firms (see Appendix B). 
TABLE 1 - DESCRIPTIVE STATISTICS 1983-1991

\begin{tabular}{|c|c|c|c|c|}
\hline & \multirow[t]{2}{*}{ All Firms } & \multicolumn{3}{|c|}{ Comovement } \\
\hline & & Low & Medium & High \\
\hline \multirow[t]{3}{*}{ Investment } & 0.082 & 0.084 & 0.086 & 0.072 \\
\hline & $(0.002)$ & $(0.004)$ & $(0.003)$ & $(0.003)$ \\
\hline & {$[0.064]$} & {$[0.067]$} & {$[0.064]$} & {$[0.054]$} \\
\hline \multirow[t]{3}{*}{ Sales growth } & 0.049 & 0.058 & 0.051 & 0.039 \\
\hline & $(0.005)$ & $(0.009)$ & $(0.008)$ & $(0.011)$ \\
\hline & {$[0.049]$} & {$[0.058]$} & {$[0.048]$} & [0.046] \\
\hline \multirow[t]{3}{*}{ Sales-assets ratio } & 0.310 & 0.336 & 0.269 & 0.409 \\
\hline & $(0.013)$ & $(0.022)$ & $(0.020)$ & $(0.027)$ \\
\hline & {$[0.365]$} & {$[0.388]$} & {$[0.322]$} & [0.475] \\
\hline \multirow[t]{3}{*}{ Cash flow } & 0.061 & 0.058 & 0.059 & 0.058 \\
\hline & $(0.003)$ & $(0.006)$ & $(0.005)$ & $(0.006)$ \\
\hline & {$[0.078]$} & {$[0.082]$} & {$[0.077]$} & {$[0.068]$} \\
\hline \multirow[t]{3}{*}{ Working capital } & 0.011 & 0.011 & 0.007 & 0.014 \\
\hline & $(0.002)$ & $(0.003)$ & $(0.005)$ & $(0.005)$ \\
\hline & {$[0.012]$} & {$[0.159]$} & {$[0.009]$} & [0.013] \\
\hline \multirow[t]{3}{*}{ Long-term debt } & 0.125 & 0.117 & 0.134 & 0.116 \\
\hline & $(0.003)$ & $(0.007)$ & $(0.005)$ & $(0.006)$ \\
\hline & {$[0.087]$} & {$[0.073]$} & {$[0.092]$} & [0.083] \\
\hline \multirow[t]{3}{*}{$\Delta$ Long-term debt } & 0.006 & 0.018 & 0.005 & 0.001 \\
\hline & $(0.003)$ & $(0.009)$ & $(0.003)$ & $(0.003)$ \\
\hline & {$[0.000]$} & {$[-0.000]$} & {$[0.000]$} & {$[0.000]$} \\
\hline $\mathrm{N}$ & 206 & 48 & 96 & 48 \\
\hline
\end{tabular}

Notes: variable means are reported, standard errors are in parentheses, medians in square brackets. Investment is defined as changes in tangible fixed assets due to purchase or production over total assets; Sales growth is the first difference of the natural logarithm of total sales; Sales-assets ratio is the log of sales less the log of total assets; Cash flow measures earnings after interest and taxes, but before depreciation and dividends over total assets; Working capital measures investment in cash, inventories and short term claims less short-term debt relative to total assets; $(\Delta)$ Long term debt is (the change in) long-term debt over total assets. Comovement is low when the firm-industry sales growth correlation is less than -0.206 (the $25^{\text {th }}$ percentile), it is medium when this correlation is in between -0.206 and 0.363 (the $75^{\text {th }}$ percentile) and it is high when the correlation exceeds 0.363 .

the information in Table 1 cannot discard an explanation along the lines of irreversible investment. Specifically, with a valuable option to delay investment, planned investment should also be lower for high-comovement firms. A lower investment demand furthermore reduces a firm's demand for external funds, which then explains its lower rate of long-term debt accumulation. Distinguishing be- 
tween these two alternative explanations requires a more careful look at the investment decision, to which we turn now.

\section{ESTIMATION RESULTS}

\subsection{Comovement and Financing Constraints}

We estimate equation (2) for the period 1986-1996 and present the estimation results in Table $2 .{ }^{12}$ A noteworthy observation in the estimates reported in column (1) pertains to the significant and negative estimate on sales growth, which is counterintuitive and likely follows from the omission of non-linear cash flow effects (note that sales growth has a positive estimated parameter in columns (2) to (5)). Furthermore, note that the effects of cash flow (positive) and working capital investment (negative) have the expected signs and are also statistically significant. As explained in section 2, we are particularly interested in the effects on investment of these two variables for firms that are most and least likely to face financing constraints. Hence, we have interacted these variables with dummies indicating low comovement $\left(D^{L C}\right)$ and high comovement $\left(D^{H C}\right)$ in columns (2) and (3) of the table.

The results in column (2) show that investment of low comovement firms is less sensitive to the inflow of cash than investment of medium and high comovement firms, but the same applies to the sensitivity of investment to cash flow for the high comovement firms relative to medium comovement firms. Similar results obtain when interactions with working capital investment are added to the empirical investment equation, as shown in column (3). There we observe that for low comovement firms working capital investment is least threatening as a competitor to investment in fixed assets for internal funds. ${ }^{13}$ As before for cash flow, however, working capital investment is also less threatening as a competitor for high comovement firms when compared to the medium comovement firms.

These results support our conjecture that low comovement associates with a relatively high value of a firm's assets as collateral to loans. Put differently, the interaction effects with $D^{L C}$ support the dominance of the supply channel - discussed in section 3.1 - arguing that although these are the firms for which the

12 Including lagged investment in the regression equation; requiring at least the presence of investment lagged two periods as an instrument, and; first-differencing in the estimation procedure each consume 1 year of data. Note that none of the specification tests in the table reject 1) our assumption concerning the absence of serial correlation in the error term, or 2) our choice of instruments. Refer to Appendix A for a more elaborate exposition of the econometric methods.

13 The magnitude of the parameter estimate is much lower than that presented in for instance Fazzari and Petersen (1993). Their estimate, derived from a Q-model, is -0.43 (-0.18) for (un)constrained firms. For regressions including sales, they still find a working capital impact of -0.22 . Our findings are more in line with Weigand and Audretsch (1999), who find a working capital impact on investment of -0.12 within a reduced-form investment equation approach. 
TABLE 2 - SALES COMOVEMENT AND FINANCING CONSTRAINTS

\begin{tabular}{|c|c|c|c|c|c|}
\hline \multirow[t]{2}{*}{ Explanatory variables } & \multicolumn{3}{|l|}{ 1986-1996 } & \multicolumn{2}{|l|}{ 1992-1996 } \\
\hline & (1) & (2) & (3) & (4) & (5) \\
\hline Investment $_{\mathrm{t}-1}$ & $\begin{array}{c}0.488 \\
(0.007)\end{array}$ & $\begin{array}{c}0.464 \\
(0.005)\end{array}$ & $\begin{array}{c}0.463 \\
(0.005)\end{array}$ & $\begin{array}{c}0.522 \\
(0.008)\end{array}$ & $\begin{array}{c}0.525 \\
(0.008)\end{array}$ \\
\hline Sales growth ${ }_{t}$ & $\begin{array}{c}-0.025 \\
(0.003)\end{array}$ & $\begin{array}{c}0.004 \\
(0.002)\end{array}$ & $\begin{array}{c}0.004 \\
(0.003)\end{array}$ & $\begin{array}{c}0.021 \\
(0.004)\end{array}$ & $\begin{array}{c}0.022 \\
(0.004)\end{array}$ \\
\hline 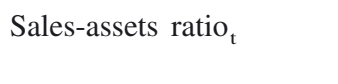 & $\begin{array}{l}0.013 \\
(0.001)\end{array}$ & $\begin{array}{l}0.015 \\
(0.001)\end{array}$ & $\begin{array}{c}0.015 \\
(0.001)\end{array}$ & $\begin{array}{c}0.014 \\
(0.001)\end{array}$ & $\begin{array}{c}0.014 \\
(0.001)\end{array}$ \\
\hline Cash flow $_{t}$ & $\begin{array}{c}0.084 \\
(0.005)\end{array}$ & $\begin{array}{c}0.102 \\
(0.004)\end{array}$ & $\begin{array}{c}0.125 \\
(0.005)\end{array}$ & $\begin{array}{c}0.037 \\
(0.007)\end{array}$ & $\begin{array}{c}0.053 \\
(0.008)\end{array}$ \\
\hline Working capital $_{\mathrm{t}}$ & $\begin{array}{r}-0.134 \\
(0.006)\end{array}$ & $\begin{array}{r}-0.137 \\
(0.006)\end{array}$ & $\begin{array}{r}-0.214 \\
(0.009)\end{array}$ & $\begin{array}{r}-0.056 \\
(0.006)\end{array}$ & $\begin{array}{r}-0.124 \\
(0.013)\end{array}$ \\
\hline$D^{L C} \times$ Cash flow $_{\mathrm{t}}$ & & $\begin{array}{r}-0.063 \\
(0.005)\end{array}$ & $\begin{array}{c}-0.084 \\
(0.006)\end{array}$ & $\begin{array}{r}-0.018 \\
(0.009)\end{array}$ & $\begin{array}{r}-0.027 \\
(0.011)\end{array}$ \\
\hline$D^{L C} \times$ Working capital $_{\mathrm{t}}$ & & & $\begin{array}{c}0.134 \\
(0.012)\end{array}$ & & $\begin{array}{c}0.105 \\
(0.013)\end{array}$ \\
\hline$D^{H C} \times$ Cash flow $_{\mathrm{t}}$ & & $\begin{array}{r}-0.040 \\
(0.006)\end{array}$ & $\begin{array}{r}-0.059 \\
(0.007)\end{array}$ & $\begin{array}{c}0.026 \\
(0.010)\end{array}$ & $\begin{array}{c}0.021 \\
(0.014)\end{array}$ \\
\hline$D^{H C} \times$ Working capital ${ }_{t}$ & & & $\begin{array}{c}0.090 \\
(0.011)\end{array}$ & & $\begin{array}{c}0.050 \\
(0.020)\end{array}$ \\
\hline Firms & 192 & 192 & 192 & 192 & 192 \\
\hline Observations & 2112 & 2112 & 2112 & 960 & 960 \\
\hline Constant included & YES & YES & YES & YES & YES \\
\hline Year dummies included & YES & YES & YES & YES & YES \\
\hline Joint significance & $\begin{array}{l}\chi^{2}(5)= \\
7890.59^{* * *}\end{array}$ & $\begin{array}{l}\chi^{2}(7)= \\
22297.69^{* * *}\end{array}$ & $\begin{array}{l}\chi^{2}(9)= \\
21494.83^{* * *}\end{array}$ & $\begin{array}{l}\chi^{2}(7)= \\
7000.54^{* * *}\end{array}$ & $\begin{array}{l}\chi^{2}(9)= \\
7791.79^{* * *}\end{array}$ \\
\hline Sargan & $\begin{array}{c}\chi^{2}(144)= \\
161.67\end{array}$ & $\begin{array}{c}\chi^{2}(190)= \\
179.17\end{array}$ & $\begin{array}{c}\chi^{2}(188)= \\
178.03\end{array}$ & $\begin{array}{c}\chi^{2}(123)= \\
138.42\end{array}$ & $\begin{array}{c}\chi^{2}(121)= \\
134.96\end{array}$ \\
\hline SOSC & 0.26 & 0.46 & 0.52 & -0.41 & -0.47 \\
\hline DSargan $\left(\mathrm{Y}_{\mathrm{t}-2}\right)$ & $\begin{array}{c}\chi^{2}(11)= \\
9.47\end{array}$ & $\begin{array}{r}\chi^{2}(11)= \\
2.59\end{array}$ & $\begin{array}{r}\chi^{2}(11)= \\
4.34\end{array}$ & $\begin{array}{r}\chi^{2}(5)= \\
5.28\end{array}$ & $\begin{array}{r}\chi^{2}(5)= \\
4.34\end{array}$ \\
\hline DSargan $\left(X_{t-1}\right)$ & $\begin{array}{c}\chi^{2}(44)= \\
48.53\end{array}$ & $\begin{array}{r}\chi^{2}(88)= \\
61.00\end{array}$ & $\begin{array}{r}\chi^{2}(88)= \\
62.23\end{array}$ & $\begin{array}{c}\chi^{2}(40)= \\
46.48\end{array}$ & $\begin{array}{c}\chi^{2}(40)= \\
44.62\end{array}$ \\
\hline
\end{tabular}

Notes: GMM estimates of Investment $t_{t}$, defined as before. Standard errors are robust to heteroskedasticity and reported in parentheses. $D^{L C(H C)}$ is a dummy that takes value 1 when the firm is in the lowest (highest) comovement quartile in the 1983-1991 period and 0 otherwise. All other variables are defined as before. The instrument set for the column (1) estimates consists of Investment lagged two and three periods and Sales growth, Salesassets ratio, Cash flow, and Working capital lagged one, two and three periods. The instrument set for the column (4) and (5) estimates additionally includes $D^{L C(H C)} \times$ Cash flow and $D^{L C(H C)} \times$ Working capital lagged one, two and three periods. The instrument 
demand for external finance is probably strongest, the superior collateral value of their assets facilitates access to external funding and reduces the incidence of financing constraints. More importantly, these are not the expected results if comovement affects investment primarily - via partial irreversibility - through the demand channel. Then the interaction effects with $D^{L C}$ should have pointed in the other direction.

In contrast, for high comovement firms, the demand channel appears important. According to this channel, high comovement firms choose a more cautious investment path, which results in them running into binding financing constraints less often. This explains why our empirical results show that their investment is less sensitive to the generation of cash flow and why working capital investment appears less threatening as a competitor to investment in fixed assets for internal funds.

We support this seemingly contradictory explanation of the results by noting that the estimation period contains a reasonable period in the eighties, where uncertainty concerning the economic recovery may have had a strong influence on both the access of firms to external sources of finance and their conservatism in seizing uncertain investment opportunities. This conjecture is inspected in columns (4) and (5), where we report estimates for the period 1992-1996. ${ }^{14}$ At least three features of these results are interesting in this regard. First, the sensitivity of investment to cash flow is considerably lower in this sub period than it was before when assessed over the entire sample period. This suggests that financing constraints were indeed less relevant during the period 1992-1996 than they were in the second half of the eighties. ${ }^{15}$ Second, for high comovement firms the re-

14 This estimation period conveniently coincides with the one used and motivated in the next subsection.

15 Credit and stock market information confirms the claim that the 1992-1996 period was more favourable for firms to attract external finance than the years before. For instance due to favourable stock price developments, proceeds from stock issues for firms from 1992 onwards - excepting 1995

set for the column (2) and (3) estimates is similar, but excludes the third lags of all explanatory variables (excluding lagged Investment) to prevent an explosion of the number of instruments. Joint significance for all variables in the model (except for a constant and the time dummies) is tested with a Wald test. Sargan refers to the Sargan test for overidentifying restrictions and is also heteroskedasticity-consistent (cf. Arellano and Bond (1991)). SOSC tests for second-order autocorrelation and is based on estimates of the residuals in first differences (cf. Arellano and Bond (1998)). The Difference Sargan (DSargan) statistics restrict the instrument set. Defining the instrument set upon which the estimates are based as $\mathrm{Y}_{\mathrm{t}-2}, \mathrm{Y}_{\mathrm{t}-3}, \mathrm{X}_{\mathrm{t}-1}, \mathrm{X}_{\mathrm{t}-2}, \mathrm{X}_{\mathrm{t}-3}$ (with $\mathrm{X}$ the vector of explanatory variables), DSargan $\left(\mathrm{Y}_{\mathrm{t}-2}\right)$ excludes $\mathrm{Y}_{\mathrm{t}-2}$ from this set and re-assesses the overidentifying restrictions. Refer to Appendix A for a more elaborate exposition of the estimation procedure and the test statistics. For all test statistics, significance at the 5 and 1 percent error level is indicated by ${ }^{*}$ and ${ }^{* *}$, respectively. 
sults suggest that the supply channel effect now dominates - as it did and still does for low comovement firms - since interactions of $D^{H C}$ with cash flow have changed sign compared to columns (2) and (3) and are now significantly positive. ${ }^{16}$ This is in line with the view that uncertainty regarding the timing of economic recovery may have been relevant in the second half of the eighties, but was largely resolved in the 1992-1996 period. The third interesting observation bolsters this conclusion. Namely, firms respond more strongly to expected profitability of investment when there is a low degree of aggregate uncertainty and financing constraints are alleviated, which shows in the significant and positive responsiveness of investment to sales growth in the 1992-1996 period.

\subsection{Comovement: Old Wine in New Bottles?}

The aim of this paper is to understand to what extent costly liquidation affects the dependence of investment on cash flow. To the extent that our classification on comovement sorts out typical firms in terms of leverage, maturity, or retention practice, however, it has no additional explanatory power over these alternative proxies for the extent to which firms face financing constraints. For the remainder of this section, therefore, we consider three firm-specific classification schemes that have frequently appeared in the literature to identify constrained firms. First, we check whether they sort out as constrained the same firms that we sorted out using comovement. Second, we briefly assess whether they associate with observed investment cash flow sensitivity patterns as is documented in the literature.

We have argued that comovement reduces the value of a firm's assets as collateral to loans. This makes high comovement firms more likely to run into binding debt capacity constraints. Insofar as high comovement sorts out low leverage firms and vice versa as a result, our findings merely repeat those obtained from a split on leverage as studied by for instance Whited (1992) and Hu and Schiantarelli (1998). Hence we consider the dependence of leverage and comovement classifications. Furthermore, to the extent that young firms perform more volatile relative to mature firms, comovement may also sort out firms on the basis of maturity. While we have no direct measure of the maturity of the firms in our sample, we assume that mature firms are typically large and retain a relatively

\footnotetext{
- were 3 to 7 times larger than those in the years 1986-1991 (source: De Nederlandsche Bank). Furthermore, the growth of credit granted by financial institutions to the private sector - more or less constant up to the end of 1993 - started picking up and increased up until late 1998 (source: De Nederlandsche Bank). See for instance van Ees et al. (1997) for an empirical demonstration of financing constraints being more relevant in bust periods than in boom periods.

16 Note, though, that the interaction term with working capital investment still has the wrong sign in this respect.
} 
small fraction of earnings (i.e. they pay generous dividends). ${ }^{17}$ This motivates an assessment of the dependence of size, retention and comovement classifications.

When sorting firms on the basis of easily adjustable variables such as the retention rate or leverage (but also size through takeovers and divestitures) we must consider the possibility that firms self-select into the constrained or unconstrained classes following unobserved innovations in investment opportunities. Hence we distinguish between a classification and an estimation period in order to ensure that the classification scheme is reasonably exogenous to the investment decision of the firm. ${ }^{18}$ We classify firms during the years 1983-1991 and estimate equation (2) over the remaining period 1992-1996. On the one hand this relatively long classification period ensures that if we classify a firm to be constrained during this period, it is likely to reflect a more or less structural status, which increases the likelihood that such a firm remains constrained for a substantial part of the estimation period. The latter period, on the other hand, is still sufficiently long to obtain meaningful parameter estimates (and coincides with the period for which comovement results are reported in columns (4) and (5) of Table 2).

Panel A of Table 3 shows the distribution of firms across constrained and unconstrained classes. ${ }^{19}$ We note that the size classification effectively sorts out the 45 largest Dutch firms: the average value of total assets for large firms in 1991 was NLG 2,974 million, as compared to NLG 196 million for the other firms. This reflects the structure of the Dutch corporate sector well, where there is a small group of very large multinationals. It also sorts out the most mature firms, which have access to external finance not only through Dutch, but also through international capital markets. Our leverage classification sorts out 52 highly leveraged firms with an average debt to assets ratio of 0.65 . For the remaining 154 firms, the corresponding figure is only 0.44 .

For the purpose of the present analysis, we are specifically interested in the extent to which the status of a firm according to our comovement classification is independent from the status of a firm according to an alternative classification

17 See footnote 8 for studies on size and maturity in relation to financing constraints. The notion that high retention firms are more likely to face binding financing constraints is well-established. See for instance Fazzari et al. (1988), Oliner and Rudebusch (1992), Bond and Meghir (1994), Hubbard et al. (1995), Elston (1996), and van Ees et al. (1998) to name just a few.

18 Note that it is more difficult to imagine that firms can or want to adjust the way they operate relative to their environment following such innovations, which is why we did not stress this distinction in the analysis of comovement's effect on investment behaviour.

19 Retention practice could not be determined for 5 firms as they had not issued shares for a meaningful part of the classification period. Also, Fazzari et al. (1988) consider a medium retention class and we do not, because only 10 firms satisfy the criterion (i.e. retention rates of $80-90 \%$ ) and widening this medium class (to retention rates of $75-90 \%$ and even $70-90 \%$ ) did not solve this problem sufficiently. For size and leverage, separate low and medium classes were identified, but merged on the basis of initial estimation results. 
ALLARD BRUINSHOOFD AND WILKO LETTERIE

TABLE 3 - WHAT COMOVEMENT DOES NOT PROXY FOR

Panel A Alternative classifications of firms

\begin{tabular}{lrrrr}
\hline & Comovement & Retention & Size & Leverage \\
\hline Low/Small & 48 & 192 & 161 & 154 \\
Medium & 96 & & & 52 \\
High/Large & 48 & 82 & 45 & 206 \\
Total & 192 & 201 & 206 &
\end{tabular}

Panel B The relationships among alternative classifications

\begin{tabular}{lrrrr}
\multicolumn{1}{l}{ Comovement } & \multicolumn{1}{l}{ Retention } & \multicolumn{1}{l}{ Size } & \multicolumn{1}{l}{ Leverage } \\
Comovement & & $\chi^{2}(2)=2.064$ & $\chi^{2}(2)=0.093$ & $\chi^{2}(2)=3.370$ \\
Retention & 0.054 & & $\chi^{2}(1)=4.689^{*}$ & $\chi^{2}(1)=16.116^{* * *}$ \\
Size & 0.018 & $-0.153^{*}$ & & $\chi^{2}(1)=1.997$ \\
Leverage & -0.017 & $0.283^{* *}$ & 0.098 & \\
\hline
\end{tabular}

Notes: all classification schemes use the 1983-1991 period. Comovement is low, medium, and high as defined before. Retention is high if the firm paid out less than ten percent of earnings in dividends in 6 years or more. A firm is large when the value of its assets is above the $75^{\text {th }}$ percentile of the total assets distribution of its 2-digit SBI93 sector for 6 years or more. Leverage is high when the firm's average leverage ratio is above the $75^{\text {th }}$ percentile of the sample. Independence of pairs of classifications is assessed using a nonparametric goodness-of-fit test based on the difference between observed and expected classification frequencies under the null of independence: the upper-right triangle reports the concomitant Pearson $\chi^{2}$ test statistics. The lower-left triangle reports Spearman's $\rho$ to indicate the direction of association between any pair of classification criteria. Refer to Appendix $\mathrm{C}$ for more details on and the contingency tables underlying Pearsons $\chi^{2}$ and Spearman's $\rho$. Significance at the 5 and 1 percent error level is indicated by * and **, respectively.

scheme. ${ }^{20}$ Panel B therefore presents statistics on the degree of association between the rank orders that result from our classifications. Specifically, the topright shows Pearson's $\chi^{2}$ to indicate whether the distribution of firms across constrained and unconstrained classes is independent for any pair of classification schemes. The bottom left reports Spearman's $\rho$ to indicate the direction of association between the status of a firm in any two classification schemes (see Appendix $\mathrm{C}$ for the details). From the first row we conclude that independence of the comovement classification and any one of the alternative classifications can-

20 As such, for example the explanatory power of liquidation costs in the firm's capital structure i.e. the correlation of the raw comovement data with raw leverage ratios - is not a topic that falls within the main scope of this paper. 
TABLE 4 - ALTERNATIVE CLASSIFICATIONS AND FINANCING CONSTRAINTS: 1992-1996

\begin{tabular}{|c|c|c|c|}
\hline & Retention & Size & Leverage \\
\hline Investment $_{t-1}$ & $\begin{array}{c}0.579 \\
(0.010)\end{array}$ & $\begin{array}{c}0.546 \\
(0.011)\end{array}$ & $\begin{array}{c}0.529 \\
(0.010)\end{array}$ \\
\hline Sales growth ${ }_{t}$ & $\begin{array}{c}-0.002 \\
(0.005)\end{array}$ & $\begin{array}{r}-0.003 \\
(0.005)\end{array}$ & $\begin{array}{c}0.006 \\
(0.006)\end{array}$ \\
\hline Sales-assets ratio $_{t}$ & $\begin{array}{c}0.012 \\
(0.002)\end{array}$ & $\begin{array}{c}0.012 \\
(0.002)\end{array}$ & $\begin{array}{c}0.012 \\
(0.001)\end{array}$ \\
\hline Cash flow $_{t}$ & $\begin{array}{c}0.009 \\
(0.016)\end{array}$ & $\begin{array}{c}0.059 \\
(0.010)\end{array}$ & $\begin{array}{c}0.031 \\
(0.013)\end{array}$ \\
\hline Working capital $_{t}$ & $\begin{array}{c}-0.122 \\
(0.020)\end{array}$ & $\begin{array}{c}-0.093 \\
(0.016)\end{array}$ & $\begin{array}{r}-0.096 \\
(0.019)\end{array}$ \\
\hline$D^{\text {High/Large }} \times$ Cash $_{\text {flow }}$ & $\begin{array}{c}0.080 \\
(0.016)\end{array}$ & $\begin{array}{r}-0.045 \\
(0.012)\end{array}$ & $\begin{array}{c}0.070 \\
(0.013)\end{array}$ \\
\hline$D^{\text {High/Large }} \times$ Working capital ${ }_{t}$ & $\begin{array}{c}-0.029 \\
(0.026)\end{array}$ & $\begin{array}{c}0.013 \\
(0.022)\end{array}$ & $\begin{array}{r}-0.016 \\
(0.021)\end{array}$ \\
\hline Firms & 201 & 206 & 206 \\
\hline Observations & 1005 & 1030 & 1030 \\
\hline Constant included & YES & YES & YES \\
\hline Year dummies included & YES & YES & YES \\
\hline Joint significance & $\chi^{2}(7)=6970.78^{* * *}$ & $\chi^{2}(7)=6019.40^{* *}$ & $\chi^{2}(7)=7326.68^{* * *}$ \\
\hline Sargan & $\chi^{2}(93)=102.76$ & $\chi^{2}(93)=109.05$ & $\chi^{2}(93)=100.42$ \\
\hline SOSC & -0.61 & -0.31 & -0.12 \\
\hline DSargan $\left(\mathrm{Y}_{\mathrm{t}-2}\right)$ & $\chi^{2}(5)=3.00$ & $\chi^{2}(5)=1.27$ & $\chi^{2}(5)=2.86$ \\
\hline DSargan $\left(X_{t-1}\right)$ & $\chi^{2}(30)=27.87$ & $\chi^{2}(30)=37.29$ & $\chi^{2}(30)=31.07$ \\
\hline
\end{tabular}

Notes: GMM estimates of Investment $t_{t}$, defined as before. Standard errors are robust to heteroskedasticity and reported in parentheses. See Table 3 for the definition of the respective dummies and Table 1 for that of all other variables. The instrument sets consist of Investment lagged two and three periods and all other variables (including interaction terms) lagged one, two and three periods. See Table 2 for the interpretation of the test statistics.

not be rejected at conventional levels of confidence. ${ }^{21}$ Dependence is more meaningful and correlations considerably higher among the alternative classifications; firms that retain a relatively small fraction of earnings are typically large and have low leverage ratios.

21 As indicated in the previous section, one may suspect a connection between our comovement classification and a sales growth classification (Hubbard and Kashyap (1992), van Ees et al. (1997), and Elston (1998) all associate financing constraints with poor growth performance). However, applying Pearson's test of independence to our comovement classification and a simple sales growth classification provides no indication of statistical dependence. See appendix C for the contingency table. 
We also apply the firm-specific classification schemes to our empirical investment equation and report the estimation results in Table 4. We find investment cash flow sensitivity patterns that are very much in line with findings well-documented in the literature. In particular, we find that investment of high retention firms is most sensitive to cash flow. The observation from Table 3 that these firms are typically small and have high leverage ratios is also reflected in the findings that the investment of small firms and heavily indebted firms is most sensitive to cash flow.

\section{SUMMARY AND CONCLUSIONS}

Liquidation is costly and a firm's investment decision may reflect the incidence of these costs. In this paper we have demonstrated that liquidation costs - estimated as the firm-industry sales comovement - influence the sensitivity of a firm's investment decision to financial factors. In particular, in the empirical evaluation of the investment equation low liquidation costs are clearly associated with a lower sensitivity of corporate investment to financial variables. Specifically, the cash flow sensitivity of investment is lowest for firms with relatively weak comovement. We find mixed and inconclusive evidence for high-comovement firms.

Using firm-industry sales comovement as our measure of liquidation costs, we emphasise the way the firm performs in relation to its environment in explaining the working of financing constraints. In this regard we want to point out that classification schemes using firm-level characteristics such as leverage, retention practice and size - although they associate with excess sensitivity patterns in a way that is in line with the literature - do not associate with our classification using comovement. This is true even though amongst themselves, these classifications on firm-specific characteristics tell more or less the same story; it is typically the mature firm - the one that has grown large, that pays generous dividends, and has a relatively low leverage ratio - that decides on investment mostly independent of financial considerations. Comovement therefore adds new insights into the working of financing constraints: it is the way the firm performs relative to its environment that essentially drives the dependence of investment on internal finance by making liquidation, and concomitantly external finance, costly.

\section{APPENDIX A}

\section{GMM ESTIMATION OF THE DYNAMIC INVESTMENT EQUATION}

The aim of this appendix is to illustrate the basic procedure used in this paper for the estimation of a dynamic panel data model, not to provide an exhaustive overview of dynamic panel data estimation. Readers interested in further details 
on the methodology used in this paper are referred to Arellano and Bond (1991) and (1998). form:

The model we estimate is a single equation with individual effects of the

$$
y_{i t}=\alpha y_{i(t-1)}+\beta^{\prime} x_{i t}+\lambda_{t}+\eta_{i}+\nu_{i t}
$$

where $\eta$ and $\lambda$ are individual and time specific effects, respectively $x_{i t}$ is a vector of explanatory variables - that can be strictly exogenous, predetermined, or endogenous with respect to $\nu_{i t}$ - with $\beta$ the vector of associated parameters. The number of time periods available on each firm $(T)$ is 14 when we use all available years in the sample. The number of firms $(N)$ is at most 206 and varies when we consider alternative classification schemes, as explained in the main text.

Let us express the investment equation for firm $i$ as

$$
y_{i}=W_{i} \delta+\iota_{i} \eta_{i}+\nu_{i t},
$$

where $\delta$ is a vector that includes $\alpha$, the $\beta$ 's and the $\lambda$ 's, and $W_{i}$ contains vectors of the lagged dependent variable, the $x_{i t}$ 's and the time dummies. $\iota_{i}$ is a vector of ones to capture the firm-specific effect. In estimating a dynamic model, we are particularly concerned with the possible correlation between the explanatory variables and the firm-specific effect. Therefore, to make a search for instruments uncorrelated with the specific effects redundant (see Arellano and Bond (1998) for a more elaborate discussion), first differences are taken of equation (A2). Let $W_{i}^{*}$ and $y_{i}^{*}$ denote first-differences of $W_{i}$ and $y_{i}$. GMM estimates of $\delta$ then have the general form

$$
\hat{\delta}=\left[\left(\sum_{i} W_{i}^{* \prime} Z_{i}\right) A_{N}\left(\sum_{i} Z_{i}^{\prime} W_{i}^{*}\right)\right]^{-1}\left(\sum_{i} W_{i}^{* \prime} Z_{i}\right) A_{N}\left(\sum_{i} Z_{i}^{\prime} y_{i}^{*}\right),
$$

where $Z_{i}$ is a matrix that contains all variables used as instruments and

$$
A_{N}=\left(\frac{1}{N} \sum_{i} Z_{i}^{\prime} H_{i} Z_{i}\right)^{-1}
$$

with $H_{i}$ a weighing matrix. We compute one-step estimates where we use

$$
H_{i}=H_{i}^{1}=\left[\begin{array}{ccccc}
2 & -1 & \cdots- & 0 & 0 \\
-1 & 2 & \cdots- & 0 & 0 \\
\vdots & \vdots & \ddots & \vdots & \vdots \\
0 & 0 & \cdots- & 2 & -1 \\
0 & 0 & \cdots- & -1 & 2
\end{array}\right] .
$$


The results reported in the main text are two-step estimates with heteroskedasticity-consistent standard errors, which uses

$$
H_{i}=H_{i}^{2}=\hat{\nu}_{i}^{*} \hat{\nu}_{i}^{* \prime}
$$

where $\hat{\nu}_{i}^{*}$ are one-step residuals.

The consequence of the first-differencing transformation on the choice of the instrument set is the following. Ignoring the explanatory variables and the time effects, first-differencing of equation (A1) yields

$$
\left(y_{i t}-y_{i(t-1)}\right)=\alpha\left(y_{i(t-1)}-y_{i(t-2)}\right)+\left(\nu_{i t}-\nu_{i(t-1)}\right) \text {. }
$$

Since $y_{i(t-2)}$ and further lags of the level of $y_{i}$ are uncorrelated with $\left(\nu_{i t}-\nu_{i(t-1)}\right)$ they are valid instruments, provided that the $\nu_{i t}$ are serially uncorrelated. This condition is checked by assessing whether second order serial correlation is absent in the first-differenced residuals, i.e.

$$
E\left(\left(\nu_{i t}-\nu_{i(t-1)}\right)\left(\nu_{i(t-2)}-\nu_{i(t-3)}\right)\right)=0
$$

(refer to Arellano and Bond (1991) for technical details and proof of the properties of this test and further tests discussed in this appendix). More generally, instrument validity is assessed using Sargan tests of overidentifying restrictions:

$$
S=\left(\sum_{i} \hat{\nu}_{i}^{* \prime} Z_{i}\right) A_{N}\left(\sum_{i} Z_{i}^{\prime} \hat{\nu}_{i}^{*}\right)
$$

which is asymptotically chi-squared distributed with as many degrees of freedom as there are overidentifying restrictions. This test checks whether $E\left(\nu_{i}^{*} Z_{i}\right)$ is sufficiently close to zero. The validity of subsets of instruments in $Z_{i}$ can be assessed using difference Sargan tests. Let $Z_{I i}$ be a subset of $Z_{i}$, where we have dropped suspected invalid instruments. $S_{I}$ is the accompanying Sargan test statistic:

$$
S_{I}=\left(\sum_{i} \hat{\nu}_{I i}^{* \prime} Z_{I i}\right) A_{I N}\left(\sum_{i} Z_{I i}^{\prime} \hat{\nu}_{I i}^{*}\right)
$$

Then the difference Sargan test compares the Sargan test statistic for the full set of instruments (A9) with the Sargan test statistic for the restricted set of instruments (A10): DSargan $=S-S_{I}$, which has as many degrees of freedom as the number of restrictions imposed on the instrument set (and equals the difference in overidentifying restrictions for the two tests). 


\section{APPENDIX B}

\section{MEASURING FIRM-INDUSTRY SALES COMOVEMENT}

We consider the following sectors (sectors 20-39 in the SBI74 classification): Food and goodies (20/21), Textile (22), Clothing (23), Leather, shoes and leatherware (24), Wood and furniture (25), Paper and related (26), Graphic industry and publishers (27), Petroleum (28), Chemical (29), Synthetic strings and fibres (30), Rubber and synthetics processing (31), Building materials, pottery, glass (32), Basic metal (33), Metal products (34), Machines (35), Electronics (36), Transports (37), (Optical) instruments (38), and Other (39). The sector sales data at the two-digit SBI74 level can be found in 'Samenvattend overzicht van de industrie, K-160.' Price information is confidential.

We cannot compute our measure of comovement for firms in sectors 27 and 38 as price indices are not available for these sectors and hence sales cannot be deflated. Fourteen firms are in these two sectors. In addition, sales data are not available for sectors 20 and 21 separately, but only for both sectors jointly. Therefore, we deflate these combined sector sales with the average price index of the two sectors and treat these two sectors as a single one. The correlation of the price indices of the individual sectors is nearly 90 percent in levels and 70 percent in growth rates. Therefore, the loss in accuracy using the aggregate deflator is probably not large. For sectors 29 and 30 sales are likewise not reported for the sectors separately but only for the two sectors jointly. Moreover, the price index for sector 30 is unavailable as well. Since approximately ten percent of our sample consists of firms in sector 29 (but none in sector 30), we are reluctant to eliminate these observations. Instead, we deflate the combined sales of sectors 29 and 30 with the price index for sector 29. Our estimation results presented in the next section are not affected by excluding sectors 29 and 30. To save space we do not report these.

\section{APPENDIX C}

\section{TESTING THE INDEPENDENCE OF CLASSIFICATION CRITERIA}

The contingency of one classification on another is assessed using the Pearson $\chi^{2}$ test for independence. Let $\pi_{i j}$ denote the underlying bivariate probability distribution. For illustration, if $i$ denotes a firm's classification based on comovement and $j$ denotes its classification based on retention, then $\pi_{L H}$ is the probability that a firm has low comovement in combination with high retention. Let $\pi_{i}$ and $\pi_{j}$ denote the marginal distributions. Then the null hypothesis of statistical indepen- 
dence of any pair of classification criteria is $H_{0}: \pi_{i j}=\pi_{i} \pi_{j}$. With the estimated bivariate probability distribution $P_{i j}$ and marginal distributions $P_{i}$ and $P_{j}$, we expect $P_{i} P_{j} n=E_{i j}$ observations in the $\mathrm{i}^{\text {th }}$ row and the $\mathrm{j}^{\text {th }}$ column of the contingency table. Pearson's $\chi^{2}$ test for independence is based on the difference between observed and expected frequencies:

$$
\begin{aligned}
\quad \text { Pearson's } \chi^{2} \equiv \sum_{i} \sum_{j} \frac{\left(O_{i j}-E_{i j}\right)^{2}}{E_{i j}} \\
\text { d.f. }=(I-1)(J-1),
\end{aligned}
$$

where $I$ and $J$ are the number of rows and columns in the contingency table, respectively.

Because rejection of the null provides no indication of the direction of association between classification criteria, we also report Spearman's $\rho$, a measure of correlation between rank orders. Together, Pearson's $\chi^{2}$ and Spearman's $\rho$ provide an assessment of the dependence of any pair of classification criteria, as well as an indication of the direction of association between them. Table A1 shows the contingency tables used to compute these statistics (as reported in Table 3 in the main text) for comovement, retention practice, size and leverage as classification criteria. Table A2 shows the contingency table for comovement and a sales growth classification.

TABLE A1 - CONTINGENCY TABLES USED TO ASSESS INDEPENDENCE BETWEEN PAIRS

\begin{tabular}{|c|c|c|c|c|c|c|c|}
\hline & & \multicolumn{2}{|c|}{ Retention } & \multicolumn{2}{|l|}{ Size } & \multicolumn{2}{|c|}{ Leverage } \\
\hline & & Low & High & Small & Large & Low & High \\
\hline \multirow[t]{3}{*}{ Comovement } & Low & 31 & 16 & 38 & 10 & 38 & 10 \\
\hline & Medium & 49 & 43 & 76 & 20 & 66 & 30 \\
\hline & High & 28 & 20 & 37 & 11 & 39 & 9 \\
\hline \multirow[t]{2}{*}{ Retention } & Low & & & 88 & 31 & 102 & 17 \\
\hline & High & & & 71 & 11 & 50 & 32 \\
\hline \multirow[t]{2}{*}{ Size } & Small & & & & & 124 & 37 \\
\hline & Large & & & & & 30 & 15 \\
\hline
\end{tabular}
OF CLASSIFICATION CRITERIA

Note: observed frequencies in cells. 
TABLE A2 - CONTINGENCY TABLE COMOVEMENT - AVERAGE SALES GROWTH

\begin{tabular}{lrrlllr}
\hline \multicolumn{5}{c}{ Growth } & & \\
\cline { 3 - 6 } & \multicolumn{2}{c}{ Low } & Medium & High & \\
\hline Comovement & Low & 8 & 25 & 15 & Pearson's $\chi^{2}(4)=$ & 3.05 \\
& Medium & 27 & 47 & 22 & P-value $=$ & 0.55 \\
& High & 14 & 22 & 12 & Spearman's $\rho=$ & -0.09 \\
& & & & & P-value $=$ & 0.20 \\
\hline
\end{tabular}

Note: observed frequencies in cells. A firm's growth rate is low (high) when its average annual sales growth rate is below (above) the $25^{\text {th }}\left(75^{\text {th }}\right)$ percentile of the sample during the period 1983-1991. Low growth firms exhibit an average annual sales growth rate of $12.6 \%$, medium growth firms grew at an average 5.2\% and low growth firms contracted annually by $3.3 \%$.

\section{REFERENCES}

Abel, A.B. and J.C. Eberly (1994), 'A Unified Model of Investment Under Uncertainty,' American Economic Review, 84, pp. 1369-1384.

Arellano, M. and S.R. Bond (1991), 'Some Tests of Specification for Panel Data: Monte Carlo Evidence and an Application to Employment Equations,' Review of Economic Studies, 58, pp. 277297.

Arellano, M. and S.R. Bond (1998), 'Dynamic Panel Data Estimation using DPD98 for Gauss: A Guide for Users,' Institute for Fiscal Studies Working Paper, 88/15.

Bond, S.R. and C. Meghir (1994), 'Dynamic Investment Models and the Firm's Financial Policy,' Review of Economic Studies, 61, pp. 197-222.

Bond, S.R. and J. van Reenen (1999), Microeconometric Models of Investment and Employment, manuscript, Institute for Fiscal Studies, London.

Carpenter, R.E., S.M. Fazzari and B.C. Petersen (1994), 'Inventory Investment, Internal-Finance Fluctuations, and the Business Cycle,' Brookings Papers on Economic Activity, pp. 75-122.

Chirinko, R.S. and H. Schaller (1995), 'Why Does Liquidity Matter in Investment Equations,' Journal of Money, Credit, and Banking, 27, pp. 527-548.

Devereux, M. and F. Schiantarelli (1990), 'Investment, Financial Factors, and Cash Flow: Evidence from UK Panel Data,' in: R. G. Hubbard (ed.), Asymmetric Information, Corporate Finance and Investment, Chicago, University of Chicago Press, pp. 279-306.

Dixit, A.K. and R.S. Pindyck (1994), Investment Under Uncertainty, Princeton, Princeton University Press.

Ees, H. van, H. Garretsen, L. de Haan, and E. Sterken (1998), 'Investment and Debt Constraints: Evidence from Dutch Panel Data,' in: S. Brakman, H. van Ees and S. K. Kuipers (eds.), Market Behaviour and Macroeconomic Modelling, London, Macmillan Press, pp. 159-179.

Ees, H. van, G.H. Kuper and E. Sterken (1997), 'Investment, Finance and the Business Cycle: Evidence from the Dutch Manufacturing Sector,' Cambridge Journal of Economics, 21, pp. 395-407. 
Elston, J.A. (1996), 'Dividend Policy and Investment: Theory and Evidence from US Panel Data,' Managerial and Decision Economics, 17, pp. 267-275.

Elston, J.A. (1998), 'Investment, Liquidity Constraints, and Bank Relationships: Evidence from German Manufacturing Firms,' in: S.W. Black and M. Moersch (eds.), Competition and Convergence in Financial Markets: The German and Anglo-American Models; Advances in Finance, Investment and Banking, 5, Amsterdam, New York and Tokio, Elsevier Science, North-Holland, pp. 135-150.

Erickson, T. and T.M. Whited (2000), 'Measurement Error and the Relationship between Investment and Q,' Journal of Political Economy, 108, pp. 1027-1057.

Fazzari, S.M., R.G. Hubbard and B.C. Petersen (1988), 'Financing Constraints and Corporate Investment,' Brookings Papers on Economic Activity, pp. 141-195.

Fazzari, S.M., R.G. Hubbard and B.C. Petersen (2000), 'Investment-Cash Flow Sensitivities Are Useful: A Comment on Kaplan and Zingales,' Quarterly Journal of Economics, 125, pp. 695-705.

Fazzari, S.M. and B.C. Petersen (1993), 'Working Capital and Fixed Investment: New Evidence on Finance Constraints,' RAND Journal of Economics, 24, pp. 328-342.

Galeotti, M., F. Schiantarelli and F. Jaramillo (1994), 'Investment Decisions and the Role of Debt, Liquid Assets and Cash Flow: Evidence from Italian Panel Data,' Applied Financial Economics, 4, pp. 121-132.

Gilchrist, S. and C.P. Himmelberg (1995), 'Evidence on the Role of Cash Flow in Reduced-Form Investment Equations,' Journal of Monetary Economics, 36, pp. 541-572.

Gilchrist, S. and C.P. Himmelberg (1998), 'Investment, Fundamentals and Finance,' National Bureau of Economic Research (NBER) Working Paper Series, 6652.

Guiso, L. and G. Parigi (1999), 'Investment and Demand Uncertainty,' Quarterly Journal of Economics, 114, pp. 185-227.

Harris, J.R., F. Schiantarelli and M.G. Siregar (1994), 'The Effect of Financial Liberalization on the Capital Structure and Investment Decisions of Indonesian Manufacturing Establishments,' World Bank Economic Review, 8, pp. 17-47.

$\mathrm{Hu}, \mathrm{X}$. and F. Schiantarelli (1998), 'Investment and Capital Market Imperfections: A Switching Regression Approach using U.S. Firm Level Panel Data,' Review of Economics and Statistics, 80, pp. 466-479.

Hubbard, R.G. (1998), 'Capital-Market Imperfections and Investment,' Journal of Economic Literature, 36, pp. 198-225.

Hubbard, R.G. and A.K. Kashyap (1992), 'Internal Net Worth and the Investment Process: An Application to US Agriculture,' Journal of Political Economy, 100, pp. 506-534.

Hubbard, R.G., A.K. Kashyap and T.M. Whited (1995), 'Internal Finance and Firm Investment,' Journal of Money, Credit, and Banking,' 27, pp. 683-701.

Jaramillo, F., F. Schiantarelli and A. Weiss (1996), 'Capital Market Imperfections Before and After Financial Liberalization: An Euler Equation Approach to Panel Data for Equadorian Firms,' Journal of Development Economics, 51, pp. 367-386.

Oliner, S.D. and G.D. Rudebusch (1992), 'Sources of the Financing Hierarchy for Business Investment,' Review of Economics and Statistics, 74, pp. 643-654.

Schaller, H. (1993), 'Asymmetric Information, Liquidity Constraints, and the Canadian Investment,' Canadian Journal of Economics, 26, pp. 552-574

Schiantarelli, F. (1996), 'Financial Constraints and Investment: Methodological Issues and International Evidence,' Oxford Review of Economic Policy, 12, pp. 70-89.

Schiantarelli, F. and A. Sembenelli (2000), 'Form of Ownership and Financial Constraints: Panel Data Evidence from Flow of Funds and Investment Equations,' Empirica, 27, pp. 175-192. 
Shleifer, A. and R. Vishny (1992), 'Liquidation Values and Debt Capacity: A Market Equilibrium Approach,' Journal of Finance, 47, pp. 1343-1366.

Shyam-Sunder, L. and S.C. Myers (1999), 'Testing Static Tradeoff against Pecking Order Models of Capital Structure,' Journal of Financial Economics, 51, pp. 219-244.

Stiglitz, J.E. and A. Weiss (1981), 'Credit Rationing in Markets with Imperfect Information,' American Economic Review, 71, pp. 393-410.

Weigand, J. and D.B. Audretsch (1999), 'Does Science Make a Difference? Investment, Finance and Corporate Governance in German Industries,' Centre for Economic Policy Research (CEPR) Working Paper, 2056.

Whited, T.M. (1992), 'Debt, Liquidity Constraints, and Corporate Investment: Evidence from Panel Data,' Journal of Finance, 47, pp. 1425-1470.

Worthington, P.R. (1995), 'Investment, Cash Flow, and Sunk Costs,' Journal of Industrial Economics, 43, pp. 49-61. 
